\title{
Quantifying the Acidic and Basic Effects of Vegetable and Herb Species in Peat-based Substrate and Hydroponics
}

\author{
Ryan W. Dickson \\ Department of Horticulture, University of Arkansas Division of Agriculture, \\ Fayetteville, AR 72701
}

\author{
Paul R. Fisher ${ }^{1}$ \\ Environmental Horticulture Department, University of Florida Institute of \\ Food and Agricultural Sciences, Gainesville, FL 32611
}

Additional index words. ammonium, anion, cation, hydroponics, leafy greens, $\mathrm{NH}_{4}{ }^{+}: \mathrm{NO}_{3}{ }^{-}$ ratio, nitrate, $\mathrm{pH}$ management, soilless substrate

\begin{abstract}
Objectives were 1) to quantify acidic and basic effects on the root zone pH for eight vegetable and herb species grown in peat-based substrate and hydroponic nutrient solution and 2) to determine the applied $\mathrm{NH}_{4}{ }^{+}: \mathrm{NO}_{3}{ }^{-}$ratio expected to have a neutral $\mathrm{pH}$ reaction for each species during its vegetative growth phase. In one experiment, plants were grown for 33 days in substrate $(70 \%$ peat:30\% perlite by volume), and were fertilized with a nutrient solution containing 7.14 milli-equivalents $(\mathrm{mEq}) \cdot \mathrm{L}^{-1} \mathrm{~N}$ and $\mathrm{NH}_{4}{ }^{+}: \mathrm{NO}_{3}{ }^{-}$ratios ranging from 0:100 to 40:60. During the second experiment, the same species were grown in hydroponic nutrient solutions at $7.14 \mathrm{mEq} \cdot \mathrm{L}^{-1} \mathrm{~N}$ with $\mathrm{NH}_{4}^{+}: \mathrm{NO}_{3}$ ratios ranging from $0: 100$ to 30:70, and data were collected over a 6-day period. In substrate, species increased root zone $\mathrm{pH}$ when supplied 0:100 solution, except for cucumber, which did not change substrate $\mathrm{pH}$. Increasing the $\mathrm{NH}_{4}{ }^{+}: \mathrm{NO}_{3}{ }^{-}$ratio to 40:60 increased acidity and decreased pH across species. Similar trends were observed in hydroponics, in which the most basic response occurred across species with 0:100, and the most acidic response occurred with 30:70. Arugula was the only species that increased root zone $\mathrm{pH}$ with all three $\mathrm{NH}_{4}{ }^{+}: \mathrm{NO}_{3}{ }^{-}$ratios in substrate and hydroponics. In substrate and hydroponics, $\mathrm{mEq}$ of acidity (negative) or basicity (positive) produced per gram dry weight gain per plant $\left(\mathrm{mEq} \cdot \mathrm{g}^{-1}\right)$ correlated positively with $\mathrm{mEq} \cdot \mathrm{g}^{-1}$ net cation minus anion uptake, respectively, in which greater cation uptake resulted in acidity and greater anion uptake resulted in basicity. In hydroponics, the greatest net anion uptake occurred with $0: 100$, and increasing the $\mathrm{NH}_{4}^{+}: \mathrm{NO}_{3}^{-}$ratio increased total cation uptake across species. Cucumber had the most acidic effect and required less than $10 \%$ of $\mathrm{N}$ as $\mathrm{NH}_{4}{ }^{+}-\mathrm{N}$ for a neutral $\mathrm{pH}$ over time, arugula was the most basic and required more than $20 \%$ $\mathrm{NH}_{4}{ }^{+}-\mathrm{N}$, and the remaining species had neutral percent $\mathrm{NH}_{4}{ }^{+}-\mathrm{N}$ between $10 \%$ and $20 \%$ of $\mathrm{N}$. Increasing the $\mathrm{NH}_{4}^{+}: \mathrm{NO}_{3}^{-}$ratio decreased $\mathrm{Ca}^{2+}$ uptake across all species in hydroponics, which could potentially impact tip burn and postharvest quality negatively. Controlling root zone $\mathrm{pH}$ in substrate and hydroponic culture requires regular $\mathrm{pH}$ monitoring in combination with $\mathrm{NH}_{4}{ }^{+}: \mathrm{NO}_{3}{ }^{-}$adjustments and other $\mathrm{pH}$ management strategies, such as injecting mineral acid to neutralize irrigation water alkalinity or adjusting the limestone incorporation rate for substrate.
\end{abstract}

Nutrient availability for plant uptake is affected by root zone $\mathrm{pH}$, especially in the case of metal micronutrients such as $\mathrm{Fe}^{2+}$ and

Received for publication 11 Feb. 2019. Accepted for publication 27 Mar. 2019

We thank the U.S. Department of AgricultureAgricultural Research Service Floriculture and Nursery Research Initiative \#58-3607-8-725, and industry partners of the Floriculture Research Alliance at the University of Florida (floriculturealliance.org), including Knox Nursery, for supporting this research.

Thanks to James Colee from the Department of Statistics, University of Florida IFAS, for providing statistical support.

${ }^{1}$ Corresponding author. E-mail: pfisher@uff.edu.
$\mathrm{Mn}^{2+}$, which decrease in solubility as $\mathrm{pH}$ increases (Lindsay, 1979; Peterson, 1981). Several factors interact and affect root zone $\mathrm{pH}$ during soilless and hydroponic production, including $\mathrm{N}$ forms in the applied fertilizer, water alkalinity and $\mathrm{pH}$ buffering, and plant species (Bar-Yosef, 2008; Bugbee, 2004; Sonneveld and Voogt, 2009). Controlling root zone $\mathrm{pH}$ and preventing drift is, therefore, an important aspect of nutrient management.

Plants affect root zone $\mathrm{pH}$ primarily through differential uptake of cation and anion nutrients (Haynes, 1990; Lea-Cox et al., 1996; Marschner, 2012; Rengel, 2003). Plants maintain a neutral charge across root membranes, compensating for a greater net uptake of either cations or anions by roots through equivalent efflux of $\mathrm{H}^{+}$and $\mathrm{OH}^{-} / \mathrm{HCO}_{3}{ }^{-}$ions, respectively, into the root zone solution. Relative cation vs. anion uptake can be expressed as both a net difference of $\mathrm{mEq}$, or as a ratio of cation-toanion uptake (Kirkby and Knight, 1977; Rengel, 2003). Ratio values greater than one, less than one, and equal to one indicate greater cation uptake, greater anion uptake, and equal uptake, respectively. Net uptake of cations and anions has been correlated with the amount of acid and base produced in the root zone for crop species grown in field soil, soilless substrate, and hydroponic nutrient solutions (Dickson et al., 2016; Kirkby and Knight, 1977; Lea-Cox et al., 1996; Marschner, 2012; Rengel, 2003).

Nitrogen represents $\approx 70 \%$ to $80 \%$ of total nutrient uptake and can be taken up in cationic $\left(\mathrm{NH}_{4}{ }^{+}-\mathrm{N}\right)$ or anionic $\left(\mathrm{NO}_{3}{ }^{-}-\mathrm{N}\right)$ form, and therefore has a major impact on root zone pH (Lea-Cox et al., 1999; Marschner, 2012). Supplying $\mathrm{NH}_{4}{ }^{+}-\mathrm{N}$ results in root zone acidity from greater net cation uptake and efflux of $\mathrm{H}^{+}$ions following uptake of $\mathrm{NH}_{4}{ }^{+}-\mathrm{N}$ by roots (Haynes, 1990; Kirkby and Knight, 1977; Lea-Cox et al., 1999; van Beusichem et al., 1988). A supply of $\mathrm{NO}_{3}{ }^{-}-\mathrm{N}$ results in root zone basicity from $\mathrm{OH}^{-} / \mathrm{HCO}_{3}{ }^{-}$efflux following uptake by roots (Haynes, 1990; Kirkby and Knight, 1977; Lea-Cox et al., 1999; van Beusichem et al., 1988). Uptake of $\mathrm{NH}_{4}{ }^{+}-\mathrm{N}$ is favored energetically over $\mathrm{NO}_{3}{ }^{-} \mathrm{N}$ uptake when both forms are supplied (Engels and Marschner, 1995). Conversion of $\mathrm{NH}_{4}{ }^{+}-\mathrm{N}$ to $\mathrm{NO}_{3}{ }^{-}-\mathrm{N}$ by microbial nitrification also produces $\mathrm{H}^{+}$ions and root zone acidity, affecting root zone $\mathrm{pH}$ in both soilless substrate (Lang and Elliot, 1990) and recirculating hydroponic systems (Bugbee, 2004; Scharwz et al., 1999).

The effect of nutrient solution $\mathrm{NH}_{4}{ }^{+}: \mathrm{NO}_{3}{ }^{-} \mathrm{N}$ ratio on root zone $\mathrm{pH}$ has been studied in greenhouse vegetable species grown in hydroponic culture (Bar-Yosef, 2008; Conesa et al., 2009; Ikeda and Osawa, 1983; Imas et al., 1997; Savvas et al., 2006; Sonneveld and Voogt, 2009). Edible crop species are also grown in peat-based soilless substrate for container crop and food production (Hamrick, 2003; Resh, 2001). Sonneveld and Voogt (2009) and Bar-Yosef (2008) report that adjustment of the ratio of $\mathrm{N}$ forms and the total $\mathrm{N}$ concentration are strategies for managing root zone $\mathrm{pH}$ in hydroponic nutrient solution and soilless substrates. However, there is limited information comparing the $\mathrm{pH}$ effects of multiple vegetable and herb species, which would be useful in developing fertilizer and $\mathrm{pH}$ management strategies.

The objectives of this study were 1) to quantify the effects on root zone $\mathrm{pH}$ for eight vegetable and herb species grown in peat-based substrate and hydroponic nutrient solution, and 2) to determine specific $\mathrm{NH}_{4}{ }^{+}: \mathrm{NO}_{3}{ }^{-}$ratios for each species estimated to have a neutral $\mathrm{pH}$ effect in both substrate and hydroponic conditions during the vegetative growth stage. Species $\mathrm{pH}$ effect was 
quantified as $\mathrm{mEq}$ of root zone aciditybasicity per gram dry weight gain per plant in substrate and hydroponics. For plants grown in substrate, cation/anion uptake was determined by analyzing dry tissue of plants supplied with 0:100 solution, where $100 \%$ of $\mathrm{N}$ was supplied in $\mathrm{NO}_{3}{ }^{-}$form and all $\mathrm{N}$ was assumed to be taken up as an anion. In hydroponics, cation/anion uptake was measured as the depletion of individual nutrients from the nutrient solution during a period of $6 \mathrm{~d}$. We hypothesized that species with greater net uptake of anions than cations would produce greater $\mathrm{mEq} \cdot \mathrm{g}^{-1}$ of root zone basicity (increased $\mathrm{pH}$ ) and would therefore require a greater $\mathrm{NH}_{4}{ }^{+}: \mathrm{NO}_{3}{ }^{-}$ratio to stabilize root zone $\mathrm{pH}$.

\section{Materials and Methods}

Substrate experiment. A factorial experiment using a randomized complete block design evaluated eight species fertilized with three nutrient solution $\mathrm{NH}_{4}^{+}: \mathrm{NO}_{3}^{-} \mathrm{N}$ ratios $(0: 100,20: 40$, and $40: 60)$ from a $0.5 \times$ modified Hoagland's solution supplied at 7.14 $\mathrm{mEq} \cdot \mathrm{L}^{-1} \mathrm{~N}$ for effects on root zone aciditybasicity. Seedling plugs of eight edible species were transplanted from 144-cell trays (Knox Nursery, Winter Garden, FL.) into four-cell plastic bedding plant containers (88 $\mathrm{mL} /$ cell or $352 \mathrm{~mL} /$ container) at one plant per cell (four plants per container). There were six replicates per treatment, where each replicate was one four-cell container. Species consisted of arugula (Eruca sativa Mill.), basil (Ocimum basilicum L., 'Genovese'), bell pepper (Capsicum anuum L., 'Yankee'), cucumber (Cucumis sativas L., 'Marketmore 76'), eggplant (Solanum melongena L., 'Galine F1'), lettuce (Lactuca sativa L., 'Green Star Green Grand Rapids'), spinach (Spinacia oleracea L., 'Tyee F1'), and tomato (Solanum lycopersicum L., 'Big Beef').

The substrate was $70 \%$ peat $/ 30 \%$ perlite (v/v) using Canadian sphagnum peat (Sun Gro Horticulture, Bellevue, WA) with long fibers and little dust [Von Post scale, 1-2 (Puustjarvi and Robertson, 1975)]. Hydrated dolomitic limestone [Graymont Western Lime, Inc., West Bend, WI; 97\% $\mathrm{Ca}(\mathrm{OH})_{2} \cdot \mathrm{MgO}$, of which $92 \%$ passed through a $45-\mu \mathrm{m}$ mesh and had an acid neutralizing value of $140 \%$ calcium carbonate equivalents (CCE)] was incorporated at $1.67 \mathrm{~kg} \cdot \mathrm{m}^{-3}$ substrate to adjust $\mathrm{pH}$ to 6.0. Plants were grown on benches in a controlled-environment growth chamber located at the University of Florida in Gainesville, FL, for $33 \mathrm{~d}$. Lighting was supplied by cool-white fluorescent bulbs $(32 \mathrm{~W}, 6500 \mathrm{~K})$ at $175 \mu \mathrm{mol} \cdot \mathrm{m}^{-2} \cdot \mathrm{s}^{-1}$ with an 18-h photoperiod that provided a daily light integral of $11.3 \mathrm{~mol} \cdot \mathrm{m}^{-2} \cdot \mathrm{d}^{-1}$ photosynthetically active radiation. Daily air and substrate temperatures during the experiment were $22.7 \pm 1.5^{\circ} \mathrm{C}$ and $23.3 \pm 1.6^{\circ} \mathrm{C}($ mean $\pm \mathrm{SD})$, respectively.

Modified nutrient solutions $(0.5 \times$ Hoagland's nutrient solution) were mixed with reagent-grade salts in zero alkalinity deion- ized water. Macronutrients were supplied at $\left(\mathrm{mEq} \cdot \mathrm{L}^{-1}\right) 7.14 \mathrm{~N}, 0.52 \mathrm{P}, 2.99 \mathrm{~K}, 5.00$ $\mathrm{Ca}$, and $1.00 \mathrm{Mg}$. Sulfate increased with $\mathrm{NH}_{4}{ }^{+}: \mathrm{NO}_{3}{ }^{-}$ratio because $\mathrm{NH}_{4}{ }^{+}-\mathrm{N}$ was supplied from ammonium sulfate, and $\mathrm{S}$ concentration was $2.38,3.80$, and $7.06 \mathrm{mEq} \cdot \mathrm{L}^{-1}$ for the $0: 100,20: 80$, and $40: 60$ solutions, respectively. Macronutrients were derived from $\left(\mathrm{NH}_{4}\right)_{2} \mathrm{SO}_{4}, \mathrm{Ca}\left(\mathrm{NO}_{3}\right)_{2} \cdot 4 \mathrm{H}_{2} \mathrm{O}, \mathrm{KH}_{2} \mathrm{PO}_{4}$, $\mathrm{MgSO}_{4} \cdot 7 \mathrm{H}_{2} \mathrm{O}, \mathrm{CaCl}_{2} \cdot 2 \mathrm{H}_{2} \mathrm{O}, \mathrm{KNO}_{3}$, and $\mathrm{K}_{2} \mathrm{SO}_{4}$. Micronutrient concentrations were constant at $\left(\mu \mathrm{Eq} \cdot \mathrm{L}^{-1}\right) 72 \mathrm{Fe}, 36 \mathrm{Mn}, 6 \mathrm{Cu}$, $15 \mathrm{Zn}$, and 1 Mo derived from FeEDDHA (6.0\% Fe; Akzo-Nobel, Holland); $\mathrm{CuSO}_{4} \cdot 5 \mathrm{H}_{2} \mathrm{O}$, $\mathrm{MnSO}_{4} \cdot \mathrm{H}_{2} \mathrm{O}, \quad\left(\mathrm{NH}_{4}\right)_{6} \mathrm{MoO}_{2} \cdot 2 \mathrm{H}_{2} \mathrm{O}$, and $\mathrm{ZnSO}_{4} \cdot 7 \mathrm{H}_{2} \mathrm{O}$. The $\mathrm{B}$ form is primarily as an uncharged molecule at $\mathrm{pH}$ less than 7 (Marschner, 2012) and was supplied at 1.0 $\mathrm{mg} \cdot \mathrm{L}^{-1}$ from $\mathrm{H}_{3} \mathrm{BO}_{3}$.

Replicate containers were irrigated at transplant to container capacity with $150 \mathrm{~mL}$ $0: 100,20: 80$, or $40: 60$ solution at 14.28 $\mathrm{mEq} \cdot \mathrm{L}^{-1} \mathrm{~N}$, and each subsequent irrigation consisted of $100 \mathrm{~mL} /$ replicate at $7.14 \mathrm{mEq} \cdot \mathrm{L}^{-1}$ N. A plastic liner with a flat bottom was placed under each replicate to allow for leachate collection and reabsorption into the substrate.

Initial root zone $\mathrm{pH}$ was measured for 12 additional replicate containers without plants using the plug-squeeze method (Scoggins et al., 2002), during which leachate from each of the four cells per replicate was combined for measurements. Initial root zone $\mathrm{pH}$ was $5.84 \pm 0.04$ across the three solution $\mathrm{NH}_{4}{ }^{+}: \mathrm{NO}_{3}{ }^{-}$ratios. Final root zone $\mathrm{pH}$ was measured for each treatment replicate as described previously. Initial root zone $\mathrm{pH}$ (5.84) was subtracted from final root zone $\mathrm{pH}$ for each replicate to calculate change in $\mathrm{pH}$ units.

Change in $\mathrm{pH}$ was related to $\mathrm{mEq}$ of acidity or basicity produced in the root zone using a modified acid-base titration (Johnson et al., 2010). Samples of the same substrate used in this experiment, but not for growing plants, were placed in plastic zip-lock bags at $250 \mathrm{~mL}$ substrate/bag. The substrate in each bag was moistened with $150 \mathrm{~mL}$ 20:80 nutrient solution at $14.28 \mathrm{mEq} \cdot \mathrm{L}^{-1} \mathrm{~N}$. Hydrochloric acid $(0.5060 \mathrm{~N})$ was added at $0.0,4.9$, $9.9,14.9,19.8$, or $24.7 \mathrm{~mL} / \mathrm{sample}$ for an equivalent of $0,10,20,30,40$, and $50 \mathrm{mEq}$ of acid added per liter of substrate. Hydrated dolomitic lime [Graymont Western Lime, Inc., WI; $97 \% \mathrm{Ca}(\mathrm{OH})_{2} \cdot \mathrm{MgO}$, of which $92 \%$ passed through a $45-\mu \mathrm{m}$ mesh and had an acid neutralizing value of $139 \% \mathrm{CCE}$ )] was added at $0,0.09,0.18,0.27,0.36$, and $0.45 \mathrm{~g} / \mathrm{sample}$. Substrate samples were allowed to equilibrate for $7 \mathrm{~d}$ before measuring $\mathrm{pH}$. A polynomial curve [Eq. (1)] was fit relating change in $\mathrm{pH}$ units (from initial $\mathrm{pH}$ 5.84 ) to the amount of acid or base in the titration, and was used to estimate $\mathrm{mEq}$ of acid or base per liter of substrate. The $\mathrm{mEq}$ of root zone acidity and basicity produced by plants during the experiment was estimated from Eq. [1] using change in substrate $\mathrm{pH}$ units for each combination of species and $\mathrm{NH}_{4}{ }^{+}: \mathrm{NO}_{3}{ }^{-}$ratio. As mentioned previously, each replicate (one replicate $=$ one 4 -cell plastic container) contained $0.352 \mathrm{~L}$ substrate or $0.088 \mathrm{~L}$ substrate/plant, and therefore $\mathrm{mEq}$ of acidity-basicity per liter values calculated from Eq. [1] were multiplied by 0.088 for correction to $\mathrm{mEq}$ acidity-basicity produced per plant.

$\mathrm{mEq}$ of acid (- value) or base (+ value) per

$\mathrm{L}$ of substrate $=0.8780 \times \Delta \mathrm{pH}^{3}+1.3369$

$\times \Delta \mathrm{pH}^{2}+9.9856 \times \Delta \mathrm{pH}-0.2569$

Plant growth was measured as root and shoot dry weight gain during the experiment. Root and shoot tissue from seedlings and from final replicates was oven-dried for $48 \mathrm{~h}$ at $70^{\circ} \mathrm{C}$ for dry weight determination. Dry weight gain was calculated by subtracting the initial dry weight of four seedlings from the total final dry weight for each replicate (four plants per replicate) of the same species, and was then divided by four to estimate dry weight gain per plant. For each replicate, species milliequivalents of acidity-basicity per plant was divided by the dry weight gain per plant to calculate $\mathrm{mEq}$ of acidity-basicity per gram dry weight gain for subsequent analysis.

The combined dry root and shoot tissue collected from each species replicate supplied with 0:100 solution was weighed and analyzed for nutrient concentration, to determine uptake of $\mathrm{mEq}$ of cations and anions. Differentiating between $\mathrm{NH}_{4}{ }^{+}-\mathrm{N}$ and $\mathrm{NO}_{3}{ }^{-} \mathrm{N}$ uptake by tissue nutrient analysis was not possible without labeled nitrogen, and therefore cation/anion uptake was evaluated only with 0:100 solution, for which all $\mathrm{N}$ uptake was assumed to be in the anionic $\mathrm{NO}_{3}{ }^{-} \mathrm{N}$ form. Before oven-drying, roots were washed with phosphate-free detergent to remove substrate particles, and all tissue was rinsed in $0.1 N \mathrm{HCl}$ followed by deionized water. Macronutrient and micronutrient concentrations were measured using inductively coupled plasma atomic emission spectrophotometry (Quality Analytical Laboratories, Panama City, FL). The weight of individual nutrients in plants was determined by multiplying plant dry weight by tissue nutrient concentrations. The total weight of each nutrient taken up per replicate during the experiment was determined by subtracting the total nutrient weight in four seedlings (initial) from the final nutrient weight for each replicate of the same species. For each replicate, uptake of nutrient weight values were divided by four to calculate uptake per plant, and were then divided by dry weight gain (measured in grams) per plant for $\mathrm{mEq}$ of nutrient uptake per gram weight gain.

Nutrient uptake was analyzed as $\mathrm{mEq}$ of net cations or anions taken up per gram dry weight gain, which was determined by subtracting $\mathrm{mEq}$ of net anions minus cations taken up per gram dry weight gain per plant for each replicate (resulting in negative values for a net uptake of cations or positive values for a net uptake of anions). Cation/ 
anion uptake was also evaluated as cation:anion uptake ratio, and was calculated by dividing $\mathrm{mEq} \cdot \mathrm{g}^{-1}$ of net cations by $\mathrm{mEq} \cdot \mathrm{g}^{-1}$ of net anions taken up. Nutrients taken up by roots were assumed to be $\mathrm{NO}_{3}^{-}, \mathrm{H}_{2} \mathrm{PO}_{4}^{-}$, $\mathrm{SO}_{4}^{2-}, \mathrm{MoO}_{4}^{2-}, \mathrm{Cl}^{-}$for anions and $\mathrm{K}^{+}, \mathrm{Ca}^{2+}$, $\mathrm{Mg}^{2+}, \mathrm{Fe}^{2+}, \mathrm{Mn}^{2+}, \mathrm{H}_{3} \mathrm{BO}_{3}^{0}, \mathrm{Cu}^{2+}, \mathrm{Zn}^{2+}, \mathrm{Na}^{+}$, and $\mathrm{Al}^{3+}$ for cations.

Analysis of variance (ANOVA) with PROC GLM (SAS 9.4; SAS Institute, Cary, $\mathrm{NC})$ was used to evaluate plant species and fertilizer $\mathrm{NH}_{4}{ }^{+}: \mathrm{NO}_{3}{ }^{-}$ratio main and interaction effects on grams of dry weight gain per plant and $\mathrm{mEq} \cdot \mathrm{g}^{-1}$ net acidity or basicity produced in the root zone. PROC GLM ANOVA was also used to evaluate species main effects on the cation:anion uptake ratio and $\mathrm{mEq} \cdot \mathrm{g}^{-1}$ of net cation or anion uptake for plants supplied 0:100 $\mathrm{NH}_{4}{ }^{+}: \mathrm{NO}_{3}{ }^{-}$solution. Mean separation used Tukey's honestly significant difference (HSD) at the $\alpha=0 \quad 005$ significance level.

Hydroponic experiment. A factorial experiment with a randomized complete block design included a plant species factor with nine levels (arugula, basil, pepper, cucumber, eggplant, lettuce, spinach, tomato, and a no-plant control) and a nutrient solution $\mathrm{NH}_{4}{ }^{+}: \mathrm{NO}_{3}{ }^{-} \mathrm{N}$ ratio factor with three levels $(0: 100,15: 85$, and $30: 70)$ using a modified $0.5 \times$ Hoagland's solution at $7.14 \mathrm{mEq} \cdot \mathrm{L}^{-1} \mathrm{~N}$. Species and cultivars were the same as mentioned previously in "Substrate experiment."

On 27 Aug. 2015, 144-cell seedlings of arugula, basil, cucumber, eggplant, lettuce, spinach, and tomato (Knox Nursery, Apopka, FL) were transplanted into hydroponic culture vessels located in the same controlledenvironment growth chamber with the same lighting conditions as in the substrate experiment. Daily air and solution temperatures during the hydroponics experiment were $24.1 \pm 1.0^{\circ} \mathrm{C}$ and $24.1 \pm 0.9^{\circ} \mathrm{C}$, respectively.

Hydroponic culture vessels followed the design described by Dickson et al. (2016). Each hydroponic culture vessel was a $4.5-\mathrm{L}$ white plastic container with a snap-on plastic lid. Substrate particles were washed from roots using deionized water before transferring seedlings to the culture vessels. Each seedling stem was wrapped with a black neoprene collar (diameter, $5 \mathrm{~cm}$ ), which fit into a plastic mesh basket (diameter, $5 \mathrm{~cm}$ ). Mesh baskets were supported in circular holes cut into the container lid, which allowed submergence of roots into nutrient solution held by the container. The neoprene collar reduced evaporation of the nutrient solution without constricting plant stems. A black plastic air tube inserted through each container lid aerated the nutrient solution constantly. Culture vessels were wrapped in aluminum foil to reduce light transmission to the nutrient solution, prevent algae growth, and help stabilize solution temperature. Each culture vessel initially contained five plants of either arugula, basil, cucumber, eggplant, lettuce, pepper, spinach, tomato, or no plants. Each culture vessel held 4.2 L nutrient solution and occupied a $25 \times 25-\mathrm{cm}$ area of growth chamber bench space.
Seedlings were initially supplied $0.25 \times$ modified Hoagland's solution $\left(3.57 \mathrm{mEq} \cdot \mathrm{L}^{-1} \mathrm{~N}\right)$ with the $0: 100 \mathrm{NH}_{4}{ }^{+}: \mathrm{NO}_{3}{ }^{-}$ratio for $7 \mathrm{~d}$ to acclimate to hydroponic conditions. After $7 \mathrm{~d}$, the nutrient solution in each culture vessel was replenished with $4.2 \mathrm{~L}$ fresh $0.5 \times$ modified Hoagland's solution at $7.14 \mathrm{mEq} \cdot \mathrm{L}^{-1} \mathrm{~N}$ $\left(0: 100 \quad \mathrm{NH}_{4}{ }^{+}: \mathrm{NO}_{3}{ }^{-}\right)$, and culture vessels were replenished with fresh solution every $7 \mathrm{~d}$ thereafter. Solution $\mathrm{pH}$ was adjusted to 6.0 before transplant and for each fresh batch of nutrient solution using $\mathrm{HCl}$ and $\mathrm{NaOH}$ at $0.1 N$. Solution $\mathrm{pH}$ was monitored every $2 \mathrm{~d}$ and maintained between 5.5 and 6.5 by titrating with $\mathrm{HCl}$ and $\mathrm{NaOH}$ at $0.1 \mathrm{~N}$.

On 16 Sept. 2015, culture vessels were replenished with $4.2 \mathrm{~L} 0.5 \times$ modified Hoagland's nutrient solutions $\left(7.14 \mathrm{mEq} \cdot \mathrm{L}^{-1} \mathrm{~N}\right)$ with $\mathrm{NH}_{4}{ }^{+}: \mathrm{NO}_{3}{ }^{-}$ratios of $0: 100,15: 85$, and 30:70 for $2 \mathrm{~d}$ to acclimate plants to the different solution types.

Modified $0.5 \times$ Hoagland's solutions were mixed using reagent-grade salts and deionized zero alkalinity water. Macronutrients were supplied at $\left(\mathrm{mEq} \cdot \mathrm{L}^{-1}\right) 7.14 \mathrm{~N}, 0.52 \mathrm{P}$, $2.99 \mathrm{~K}, 5.00 \mathrm{Ca}$, and $1.00 \mathrm{Mg}$. Sulfate differed with $\mathrm{NH}_{4}{ }^{+}: \mathrm{NO}_{3}{ }^{-}$ratio, and $\mathrm{S}$ was $\left(\mathrm{mEq} \cdot \mathrm{L}^{-1}\right) 2.38,2.85$, and 5.30 for the $0: 100$, $15: 85$, and 30:70 solutions, respectively. Macronutrients were derived from $\left(\mathrm{NH}_{4}\right)_{2} \mathrm{SO}_{4}$, $\mathrm{Ca}\left(\mathrm{NO}_{3}\right)_{2} \cdot 4 \mathrm{H}_{2} \mathrm{O}, \mathrm{KH}_{2} \mathrm{PO}_{4}, \mathrm{MgSO}_{4} \cdot 7 \mathrm{H}_{2} \mathrm{O}$, $\mathrm{CaCl}_{2} \cdot 2 \mathrm{H}_{2} \mathrm{O}, \mathrm{KNO}_{3}$, and $\mathrm{K}_{2} \mathrm{SO}_{4}$. Micronutrient concentrations were constant at $\left(\mu \mathrm{Eq} \cdot \mathrm{L}^{-1}\right) 72 \mathrm{Fe}, 36 \mathrm{Mn}, 6 \mathrm{Cu}, 15 \mathrm{Zn}$, and 1 Mo derived from FeEDDHA $(6.0 \% \mathrm{Fe}$, Akzo-Nobel); $\mathrm{CuSO}_{4} \cdot 5 \mathrm{H}_{2} \mathrm{O}, \mathrm{MnSO}_{4} \cdot \mathrm{H}_{2} \mathrm{O}$, $\left(\mathrm{NH}_{4}\right)_{6} \mathrm{MoO}_{2} \cdot 2 \mathrm{H}_{2} \mathrm{O}$, and $\mathrm{ZnSO}_{4} \cdot 7 \mathrm{H}_{2} \mathrm{O}$. B exists as an uncharged molecule at $\mathrm{pH}$ less than 7 (Marschner, 2012) and was supplied at $1.0 \mathrm{mg} \cdot \mathrm{L}^{-1}$ from $\mathrm{H}_{3} \mathrm{BO}_{3}$.

The experiment started on 18 Sept. 2015 (day 0 ), and culture vessels were replenished with $4.2 \mathrm{~L}$ fresh $0.5 \times$ modified Hoagland's nutrient solutions (adjusted to $\mathrm{pH}$ 6.0) with $\mathrm{NH}_{4}{ }^{+}: \mathrm{NO}_{3}{ }^{-}$ratios of $0: 100,15: 85$, and 30:70. Species and solution $\mathrm{NH}_{4}{ }^{+}: \mathrm{NO}_{3}{ }^{-}$ratio effects on solution acidity-basicity produced and individual nutrient uptake was measured for each replicate for $6 \mathrm{~d}$. Each replicate consisted of one culture vessel. Each solution $\mathrm{NH}_{4}{ }^{+}: \mathrm{NO}_{3}{ }^{-}$ratio and plant species combination $\left(3 \mathrm{NH}_{4}{ }^{+}: \mathrm{NO}_{3}{ }^{-}\right.$ratios $\times 9$ species levels $=$ 27 combinations) was replicated four times ( 27 combinations $\times 4$ replicates $=108$ total replicates). Two plants per replicate were harvested on day 0 for initial data collection, and the remaining three plants per replicate continued over the 6-d period and were harvested on 24 Sept. 2015 for final data collection.

Solution $\mathrm{pH}$ was monitored in each replicate every second day until final data collection on day 6 , and $\mathrm{pH}$ was adjusted as described earlier. Initial and final solution samples were analyzed for individual nutrient ion concentration and were stored in the dark at $5{ }^{\circ} \mathrm{C}$ before analysis. Separate samples were collected for determining concentration of $\mathrm{N}$ forms. Nitrification was prevented in samples analyzed for $\mathrm{N}$ forms by adding sulfuric acid to lower the solution
$\mathrm{pH}$ of samples to less than 3. Ammoniacal and $\mathrm{NO}_{3}^{-}-\mathrm{N}$ was measured by semiautomated and automated colorimetry (University of Florida Analytical Laboratory, Gainesville, FL). All other ions were measured by inductively coupled plasma atomic emission spectrophotometry (Quality Analytical Laboratories). Nutrient concentrations in solution were converted to $\mathrm{mEq}$ values for subsequent analysis.

For each replicate, plant growth was measured as grams of dry weight gain per plant during the $6-d$ period. At day 0 , the two plants sampled destructively per replicate (culture vessel) were oven-dried at $70{ }^{\circ} \mathrm{C}$ for $48 \mathrm{~h}$ for initial root and shoot dry weight determination. The remaining three plants were sampled destructively on day 6 for final dry weight determination. For each replicate, the estimated initial dry weight per plant was subtracted from the final dry weight per plant to determine grams of dry weight gain per plant.

Net acidity or basicity produced in the root zone was calculated from the amount of acid $(\mathrm{HCl})$ and base $(\mathrm{NaOH})$ added per replicate during $\mathrm{pH}$ adjustment and the amount required on day 6 to titrate the solution back to $\mathrm{pH}$ 6.0. A positive net addition of acid $(\mathrm{HCl})$ or base $(\mathrm{NaOH})$ indicated that plants produced basicity and acidity, respectively. Titrated additions of acid and base were converted to $\mathrm{mEq}$ values. Net addition of acid or base was determined by subtracting the $\mathrm{mEq}$ of base added from the $\mathrm{mEq}$ of acid added per replicate or culture vessel, which was divided by three (three plants per replicate) and converted to $\mathrm{mEq}$ values to determine $\mathrm{mEq}$ of acidity or basicity produced per plant (a negative value indicated net acidity and a positive value indicated net basicity). For each replicate, $\mathrm{mEq}$ of aciditybasicity per plant was divided by the dry weight gain per plant and analyzed as $\mathrm{mEq}$ of net acidity-basicity per gram dry weight gain.

Individual nutrient uptake was calculated for each species-solution type combination by subtracting the $\mathrm{mEq}$ of each nutrient in solution for replicates containing plants from the average $\mathrm{mEq}$ in solution of the no-plant controls after $6 \mathrm{~d}$. Cation vs. anion uptake was analyzed as $\mathrm{mEq}$ of anions taken up minus $\mathrm{mEq}$ of cations taken up for each replicate or culture vessel, where negative values indicated net cation uptake and positive values indicated net anion uptake. The assumed nutrient forms taken up were $\mathrm{NH}_{4}{ }^{+}$, $\mathrm{K}^{+}, \mathrm{Ca}^{2+}, \mathrm{Mg}^{2+}, \mathrm{Na}^{+}, \mathrm{NO}_{3}^{-}, \mathrm{H}_{2} \mathrm{PO}_{4}^{2-}, \mathrm{SO}_{4}^{2-}$, $\mathrm{Fe}^{2+}, \mathrm{Mn}^{2+}, \mathrm{Cu}^{2+}, \mathrm{Zn}^{2+}, \mathrm{MoO}_{4}^{2-}, \mathrm{Al}^{++}, \mathrm{Cl}^{-}$, and $\mathrm{H}_{3} \mathrm{BO}_{3}^{0}$.

Net mEq cation/anion uptake per replicate was divided by three (three plants per replicate) for $\mathrm{mEq}$ of uptake per plant, then divided by the dry weight gain per plant (measured in grams) to determine $\mathrm{mEq}$ of net cation or anion uptake per gram dry weight gain. The cation:anion uptake ratio was calculated by dividing total $\mathrm{mEq} \cdot \mathrm{g}^{-1}$ of cation uptake by total $\mathrm{mEq} \cdot \mathrm{g}^{-1}$ of anion uptake. 
Analysis of variance with PROC GLM (SAS 9.4; SAS Institute, Cary, NC) was used to evaluate plant species and $\mathrm{NH}_{4}{ }^{+}: \mathrm{NO}_{3}{ }^{-}$ ratio main and interaction effects on dry weight gain per plant, $\mathrm{mEq} \cdot \mathrm{g}^{-1}$ net aciditybasicity, $\mathrm{mEq} \cdot \mathrm{g}^{-1}$ net cation or anion uptake, and the cation:anion uptake ratio. Mean separation for ANOVA used Tukey's HSD at the $\alpha=0.05$ significance level.

Expected $\mathrm{NH}_{4}{ }^{+}: \mathrm{NO}_{3}{ }^{-}$ratio for a neutral root zone $\mathrm{pH}$. Applied $\mathrm{NH}_{4}{ }^{+}: \mathrm{NO}_{3}{ }^{-}$ratios for a neutral root zone $\mathrm{pH}$ were determined for each species in substrate and hydroponics (second objective), and analyzed as the percent $\mathrm{NH}_{4}{ }^{+}-\mathrm{N}$ of total applied $\mathrm{N}$ (remainder as $\mathrm{NO}_{3}{ }^{-}-\mathrm{N}$ ) expected to result in a neutral $\mathrm{pH}$. Linear regression was used to analyze the $\mathrm{mEq} \cdot \mathrm{g}^{-1}$ net acidity-basicity (dependent variable) at the three $\mathrm{NH}_{4}{ }^{+}: \mathrm{NO}_{3}{ }^{-}$ratios (independent variable). In substrate, solutions 0:100, 20:80, and 40:60 corresponded to $0 \%, 20 \%$, and $40 \% \mathrm{NH}_{4}{ }^{+}-\mathrm{N}$ of total $\mathrm{N}$, respectively. In hydroponics, solutions $0: 100,15: 85$, and $30: 70$ corresponded to $0 \%, 15 \%$, and $30 \%$ $\mathrm{NH}_{4}{ }^{+}-\mathrm{N}$ of total $\mathrm{N}$, respectively. The analysis was run by species, with separate analyses for substrate and hydroponic experiments. Each regression curve that was significant was then solved for percent $\mathrm{NH}_{4}{ }^{+}$of total applied $\mathrm{N}$ that would result in $0 \mathrm{mEq} \cdot \mathrm{g}^{-1}$ net aciditybasicity (neutral $\mathrm{pH}$ ).

\section{Results and Discussion}

Plant growth differed between species in both experiments $(P<0.0001)$ and was affected by the $\mathrm{NH}_{4}{ }^{+}: \mathrm{NO}_{3}{ }^{-}$ratio in substrate $(P=0.0128)$, but the interaction was not significant in either experiment (Table 1). In substrate, species ranged from $0.59 \mathrm{~g}$ dry weight gain per plant with arugula to $1.34 \mathrm{~g}$ dry weight gain per plant with eggplant. Dry weight gain was the least with the 0:100 solution $(0.97 \mathrm{~g})$ and greatest with the 40:60 solution $(1.05 \mathrm{~g})$. In hydroponic solution, species dry weight gain ranged from $0.65 \mathrm{~g}$ with spinach to $2.70 \mathrm{~g}$ with tomato (Table 1).

Plant species and solution $\mathrm{NH}_{4}{ }^{+}: \mathrm{NO}_{3}{ }^{-}$ ratio had significant main and interaction effects $(P<0.0001)$ on root zone aciditybasicity for plants grown in both substrate and hydroponic experiments, analyzed separately by experiment. In the substrate experiment (Fig. 1A), changes in substrate $\mathrm{pH}$ during the 33-d experimental period were converted to $\mathrm{mEq}$ of net acidity-basicity produced per gram dry weight gain per plant. Each species produced $\mathrm{mEq} \cdot \mathrm{g}^{-1}$ net basicity and increased $\mathrm{pH}$ when supplied with the 0:100 solution compared with other solutions, except for cucumber, which had no change in $\mathrm{pH}$ with $0: 100$. An increasing $\mathrm{NH}_{4}{ }^{+}: \mathrm{NO}_{3}{ }^{-}$ratio increased the acidity produced by each species; the greatest $\mathrm{mEq} \cdot \mathrm{g}^{-1}$ net acidity in substrate occurred with the 40:60 solution. With the 40:60 solution, all species in substrate produced a net acidity and decreased $\mathrm{pH}$ except for arugula, which produced net basicity and increased $\mathrm{pH}$ in all solutions.

In the hydroponic experiment, species produced either net basicity (seven species) or had a neutral $\mathrm{pH}$ effect (spinach) with the 0:100 solution (Fig. 1B). Spinach also had a neutral effect with all solutions, indicating it was less sensitive to the $\mathrm{NH}_{4}{ }^{+}: \mathrm{NO}_{3}{ }^{-}$ratio than other species in hydroponics. However, spinach had the lowest average dry weight gain in hydroponics (Table 1), and slight $\mathrm{pH}$ effects would be more difficult to measure experimentally. Similar to trends in Fig. 1A with substrate, arugula was the only species to produce basicity with $30: 70$ solution, and overall had the most basic effect on root zone
$\mathrm{pH}$ of any species in each of the three nutrient solutions.

Characterizing species effects on root zone $\mathrm{pH}$ in units of $\mathrm{mEq} \cdot \mathrm{g}^{-1}$ net aciditybasicity allows comparison with research by Rengel (2003) and van Beusichem et al. (1988) for different species and $\mathrm{NH}_{4}{ }^{+}: \mathrm{NO}_{3}{ }^{-}$ ratios. Rengel (2003) compared 37 agronomic cereal and legume species by soil acidification, which ranged from 0.3 and 2.0 $\mathrm{mEq} \cdot \mathrm{g}^{-1}$ acidity (original units were reported as centimoles of $\mathrm{H}^{+}$per kilogram shoot dry weight). Castor (Ricinus communis $\mathrm{L}$.) grown as a model crop in hydroponic solution was shown to produce $3.70 \mathrm{mEq} \cdot \mathrm{g}^{-1}$ acidity and $1.03 \mathrm{mEq} \cdot \mathrm{g}^{-1}$ basicity when the nutrient solution contained either $\mathrm{NH}_{4}{ }^{+}-\mathrm{N}$ or $\mathrm{NO}_{3}{ }^{-}-\mathrm{N}$ as the sole $\mathrm{N}$ source, respectively (van Beusichem et al., 1988). Results from van Beusichem et al. (1988) are comparable to data in Fig. 1B. The 0:100 solution $(100 \%$ $\left.\mathrm{NO}_{3}{ }^{-}-\mathrm{N}\right)$ resulted in a maximum of 1.31 $\mathrm{mEq} \cdot \mathrm{g}^{-1}$ basicity (for arugula) in hydroponics, and extrapolating from the 30:70 solution to $100 \% \mathrm{NH}_{4}^{+}-\mathrm{N}$ (by multiplying by a factor of 3.33 , calculated as $100 \% \mathrm{NH}_{4}^{+}-\mathrm{N} \div 30 \%$ $\mathrm{NH}_{4}{ }^{+} \mathrm{N}$ ) resulted in up to $4.52 \mathrm{mEq} \cdot \mathrm{g}^{-1}$ acidity for lettuce. These data may also be useful when predicting the $\mathrm{mEq}$ of acidity or basicity added into a substrate or hydroponic system when combined with a plant growth model.

The percent $\mathrm{NH}_{4}{ }^{+}-\mathrm{N}$ of total applied $\mathrm{N}$ (remainder as $\mathrm{NO}_{3}{ }^{-}-\mathrm{N}$ ) expected to result in a neutral root zone $\mathrm{pH}$ for each species in either substrate or hydroponics was estimated using linear regression, and is summarized in Table 1. In substrate, cucumber produced a $\mathrm{mEq} \cdot \mathrm{g}^{-1}$ net acidity not different from zero when supplied with the 0:100 solution (Fig. 1A), which resulted in an estimated percent $\mathrm{NH}_{4}{ }^{+}-\mathrm{N}$ value $(2.3 \%)$ not different

Table 1. Species gram of dry weight gain per plant, percent $\mathrm{NH}_{4}{ }^{+}-\mathrm{N}$ of total supplied $\mathrm{N}$ expected to result in a neutral $\mathrm{pH}$ effect, and linear regression $R^{2}$ values analyzed separately for substrate and hydroponic experiments. ${ }^{\mathrm{z}}$

\begin{tabular}{|c|c|c|c|c|c|c|}
\hline & \multicolumn{2}{|c|}{ Dry weight gain $(\mathrm{g}) /$ plant } & \multicolumn{2}{|c|}{ Neutral $\mathrm{NH}_{4}^{+}-\mathrm{N}(\%)$} & \multicolumn{2}{|c|}{ Regression $R^{2}$} \\
\hline & Substrate & $\begin{array}{l}\text { Hydroponic } \\
\text { solution }\end{array}$ & Substrate & $\begin{array}{l}\text { Hydroponic } \\
\text { solution }\end{array}$ & Substrate & $\begin{array}{l}\text { Hydroponic } \\
\text { solution }\end{array}$ \\
\hline \multicolumn{7}{|l|}{$\overline{\text { Plant species }}$} \\
\hline Cucumber & $1.17 \mathrm{bc}$ & $0.81 \mathrm{c}$ & $2.3 \pm 5.5$ & $8.3 \pm 5.4$ & 0.83 & 0.75 \\
\hline Eggplant & $1.34 \mathrm{a}$ & $2.06 \mathrm{ab}$ & $19.4 \pm 5.0$ & $21.8 \pm 10.1$ & 0.81 & 0.72 \\
\hline Lettuce & $0.92 \mathrm{e}$ & $1.34 \mathrm{c}$ & $12.5 \pm 8.0$ & $6.6 \pm 5.7$ & 0.83 & 0.73 \\
\hline Tomato & $1.26 \mathrm{ab}$ & $2.70 \mathrm{a}$ & $16.9 \pm 3.7$ & $21.1 \pm 5.5$ & 0.83 & 0.71 \\
\hline \multicolumn{7}{|l|}{$\mathrm{NH}_{4}{ }^{+}: \mathrm{NO}_{3}{ }^{-}$ratio } \\
\hline 0:100 (substrate and hydroponic) & $0.97 \mathrm{~b}$ & $1.44 \mathrm{a}$ & & & & \\
\hline 20:80 (substrate) or 15:85 (hydroponic) & $0.99 \mathrm{ab}$ & $1.46 \mathrm{a}$ & & & & \\
\hline 40:60 (substrate) or 30:70 (hydroponic) & $1.05 \mathrm{a}$ & $1.20 \mathrm{a}$ & & & & \\
\hline Species main effects & $* * *$ & ** & & & & \\
\hline $\mathrm{NH}_{4}^{+}: \mathrm{NO}_{3}^{-}$main effects & * & NS & & & & \\
\hline
\end{tabular}

${ }^{\mathrm{z}}$ Dry weight gain data represent least-square means of 18 replicates per species and 48 replicates per $\mathrm{NH}_{4}{ }^{+}: \mathrm{NO}_{3}{ }^{-}$ratio for the substrate experiment and least-square means of 12 replicates per species and 32 replicates per $\mathrm{NH}_{4}{ }^{+}: \mathrm{NO}_{3}{ }^{-}$ratio for the hydroponic experiment. Mean separation for species and solution main effects on dry weight gain data used Tukey's honestly significant difference at $\alpha=0.05$, and means sharing the same lowercase letter were not significantly different. Linear regression consisted of percent $\mathrm{NH}_{4}{ }^{+}-\mathrm{N}$ of total $\mathrm{N}$ supplied (remainder as $\mathrm{NO}_{3}{ }^{-}-\mathrm{N}$ ) as the independent variable and milliequivalents of acidity-basicity per gram dry weight gain per plant as the dependent variable for each species. Error bars represent $\pm 95 \%$ confidence intervals for percent $\mathrm{NH}_{4}{ }^{+}-\mathrm{N}$ parameters. Linear regression slope coefficient used to calculate neutral percent $\mathrm{NH}_{4}{ }^{+}-\mathrm{N}$ values was not significant for hydroponic spinach.

${ }_{\mathrm{NS}, *, * * * * *}$ Not significant or significant at $P<0.05,0.01$, or 0.0001 , respectively.

$\mathrm{NA}=$ not applicable. 

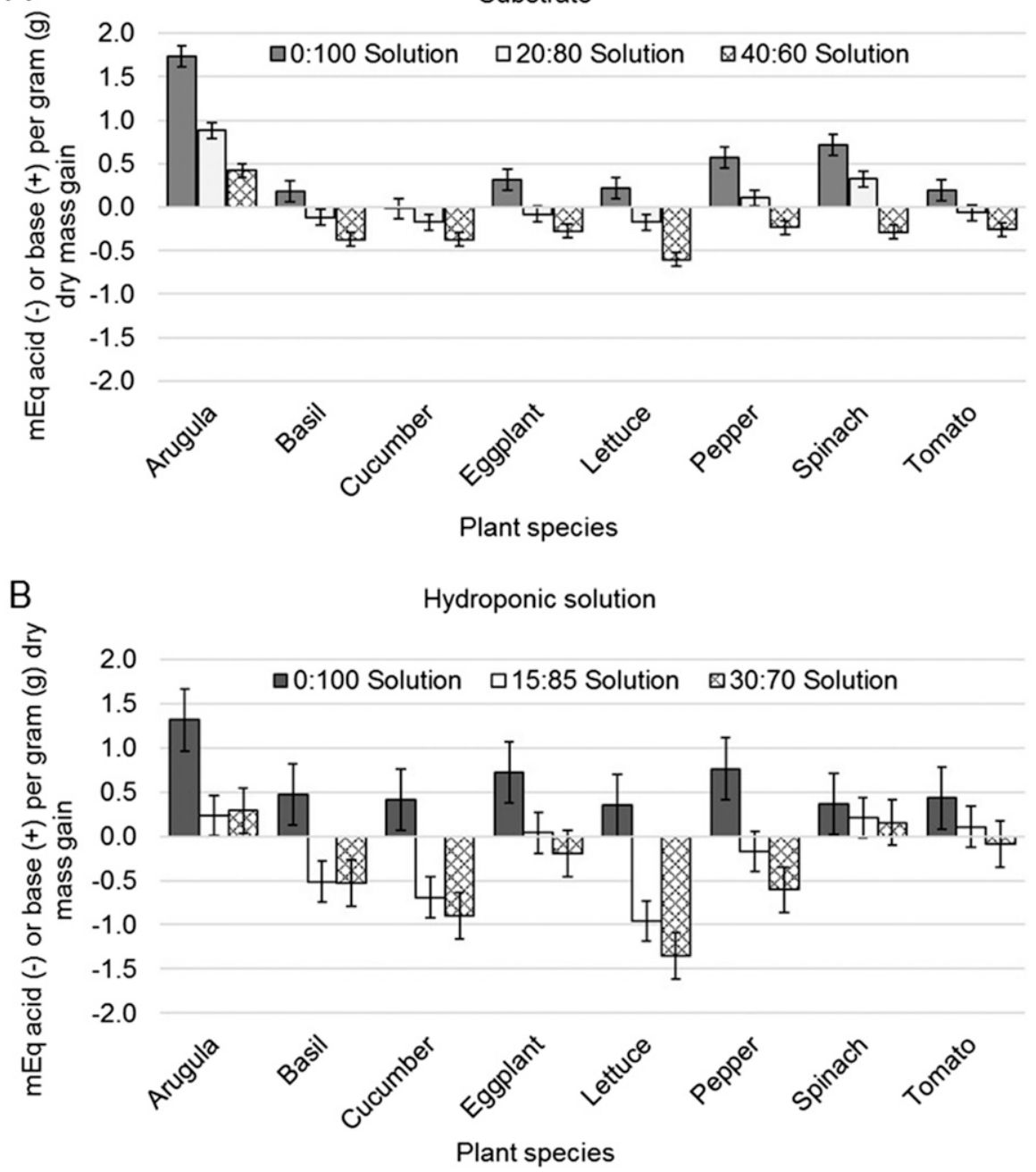

Fig. 1. Species milliequivalents $(\mathrm{mEq})$ of root zone acidity (- value) or basicity (+ value) produced per gram dry weight gain per plant (A) when grown in substrate and supplied $\mathrm{NH}_{4}{ }^{+}: \mathrm{NO}_{3}{ }^{-}$ratios of $0: 100$ 20:80, and 40:60 or (B) when grown in hydroponic nutrient solution and supplied $\mathrm{NH}_{4}{ }^{+}: \mathrm{NO}_{3}{ }^{-}$ratios of 0:100, 15:85, and 30:70. Data represent species least-square means of six replicates for (A) substrate and four replicates for $(\mathbf{B})$ hydroponic nutrient solution. Error bars are $\pm 95 \%$ confidence intervals using Tukey's honestly significant difference at $\alpha=0.05$.

from zero (Table 1). The neutral percent $\mathrm{NH}_{4}{ }^{+}-\mathrm{N}$ in substrate estimated for arugula $(46.0 \%)$ was greater than the percent $\mathrm{NH}_{4}{ }^{+}-\mathrm{N}$ in the 40:60 solution $\left(40 \% \mathrm{NH}_{4}^{+}-\mathrm{N}\right)$, which decreases the reliability of this estimate. In the case of cucumber in substrate, a complete $100 \% \mathrm{NO}_{3}{ }^{-}-\mathrm{N}$ fertilizer would therefore be needed for a neutral $\mathrm{pH}$ effect and to prevent a decrease in root zone $\mathrm{pH}$. In contrast, other species were estimated to require a combination of $\mathrm{NH}_{4}{ }^{+}-\mathrm{N}$ and $\mathrm{NO}_{3}{ }^{-}-\mathrm{N}$ to achieve a neutral $\mathrm{pH}$ in substrate, where $\mathrm{NH}_{4}{ }^{+}-\mathrm{N}$ ranged from $12.5 \%$ (lettuce) to $46.0 \%$ (arugula) of total $\mathrm{N}$.

In hydroponics, the estimated neutral percent $\mathrm{NH}_{4}{ }^{+}-\mathrm{N}$ ranged from $6.6 \%$ (lettuce) to $23.3 \%$ (arugula) of total N (Table 1). There was a positive relationship $\left(r=0.7\right.$ and $R^{2}=$ 0.5 ; data not shown) between the neutral percent $\mathrm{NH}_{4}{ }^{+}-\mathrm{N}$ estimated for hydroponics compared with the neutral estimated percent $\mathrm{NH}_{4}{ }^{+} \mathrm{N}$ in substrate when all species in Table 1 were included other than spinach (linear regression was not significant for spinach in hydroponics). This indicates that species such as arugula, which required a greater percent $\mathrm{NH}_{4}{ }^{+}-\mathrm{N}$ relative to other species in substrate, would also require a greater percent $\mathrm{NH}_{4}^{+}-\mathrm{N}$ in hydroponics compared with a lower percent $\mathrm{NH}_{4}{ }^{+}-\mathrm{N}$ for basil, cucumber, and lettuce. The estimated neutral percent $\mathrm{NH}_{4}{ }^{+}-\mathrm{N}$ was intermediate for eggplant, pepper, and tomato.

For a neutral $\mathrm{pH}$ effect, recommended values for percent $\mathrm{NH}_{4}{ }^{+}-\mathrm{N}$ of total $\mathrm{N}$ range from $5 \%$ to $10 \%$ in hydroponics and from $10 \%$ to $15 \%$ in substrate for most species (Sonneveld and Voogt, 2009). However, certain species have been reported to require percent $\mathrm{NH}_{4}{ }^{+}-\mathrm{N}$ values more than or less than recommended ranges. For example, neutral percent $\mathrm{NH}_{4}{ }^{+}-\mathrm{N}$ values of $0 \%$ and $25 \%$ were reported by Sonneveld and Voogt (2009) for melon and rose, respectively. Imas et al. (1997) found that tomato grown in nutrient solution required a neutral percent $\mathrm{NH}_{4}{ }^{+}-\mathrm{N}$ of $30 \%$, and $21.1 \% \mathrm{NH}_{4}^{+}-\mathrm{N}$ was estimated for tomato in our hydroponic experiment (Table 1). Under similar experimental conditions with floriculture species, Johnson et al. (2013) found that petunia (Petunia $\times$ hybrid Vilm.Andr.), impatiens (Impatiens wallerana Hook. F.), and zonal geranium (Pelargonium $\times$ hortorum Bailey L.H.) required $31 \%, 10 \%$, and $0 \% \mathrm{NH}_{4}{ }^{+}-\mathrm{N}$, respectively, for a neutral $\mathrm{pH}$ in peat-based substrate. Based on our results, arugula was a particularly basic species compared with other species tested in this and other studies.

Substrates and nutrient solutions were formulated using hydrated limestone and zero-alkalinity water, respectively, which would result in low buffering against change in root zone $\mathrm{pH}$. The $\mathrm{NH}_{4}{ }^{+}: \mathrm{NO}_{3}{ }^{-}$ratio required for a neutral root zone $\mathrm{pH}$ is increased when irrigating with high bicarbonate concentration because of the basic and buffering effect on $\mathrm{pH}$ (Bailey, 1996; Fisher et al., 2014). The neutral $\mathrm{NH}_{4}{ }^{+}: \mathrm{NO}_{3}{ }^{-}$ratio is decreased as total $\mathrm{N}$ concentration increases in the applied fertilizer solution because $\mathrm{NH}_{4}{ }^{+}$is a strong acid compared with $\mathrm{NO}_{3}{ }^{-}$as a base (Fisher et al., 2014). Substrate materials and cation exchange capacity are other factors that also contribute to acidity-basicity and buffering against changes in root zone $\mathrm{pH}$ (Marschner, 2012; Sonneveld and Voogt, 2009). A neutral $\mathrm{NH}_{4}{ }^{+}: \mathrm{NO}_{3}{ }^{-}$ratio is therefore highly dependent on the plant species and other conditions, and quantifying $\mathrm{pH}$ acidic and basic factors would require a complex interacting model. In horticultural practice, this complexity necessitates regular $\mathrm{pH}$ monitoring and adjustment of fertilizer or acidbase correction because of the likelihood of $\mathrm{pH}$ drift over time.

Species grown in substrate and supplied the $0: 100$ solution $\left(100 \% \mathrm{NO}_{3}{ }^{-}-\mathrm{N}\right)$ had greater uptake of anions than cations, based on tissue analysis, resulting in a cation/anion uptake ratio of less than one (Table 2). This result is consistent with previous reports of plants supplied with $\mathrm{NO}_{3}^{-}-\mathrm{N}$ only (Haynes, 1990; Kirkby and Knight, 1977; Marschner, 2012). Arugula had the lowest cation:anion ratio $(0.54)$ and greatest net $\mathrm{mEq}$ of anions taken up per gram dry weight gain (2.16 $\mathrm{mEq} \cdot \mathrm{g}^{-1}$ net anion uptake). A positive relationship was found between species $\mathrm{mEq} \cdot \mathrm{g}^{-1}$ net anion uptake and $\mathrm{mEq} \cdot \mathrm{g}^{-1}$ net basicity produced by roots (Fig. 2A). Therefore, species with greater uptake of anions than cations had a greater tendency to increase root zone $\mathrm{pH}$.

In the hydroponic experiment, increasing the $\mathrm{NH}_{4}{ }^{+}: \mathrm{NO}_{3}{ }^{-}$ratio increased the cation:anion uptake ratio and resulted in greater net uptake of cations [negative $\mathrm{mEq} \cdot \mathrm{g}^{-1}$ net cation/anion uptake (Table 2)].

Species and $\mathrm{NH}_{4}{ }^{+}: \mathrm{NO}_{3}{ }^{-}$ratio had main and interaction effects on the cation:anion uptake ratio $(P<0.01$, Table 2$)$. The significant interaction occurred because, in contrast to other species, in spinach the cation:anion uptake ratio did not increase with the $\mathrm{NH}_{4}{ }^{+}: \mathrm{NO}_{3}{ }^{-}$ratio (data not shown). 
Table 2. Cation/anion uptake ratio and milliequivalents $(\mathrm{mEq})$ net cation or anion uptake per gram dry weight gain per plant analyzed separately for substrate and hydroponic experiments. ${ }^{z}$

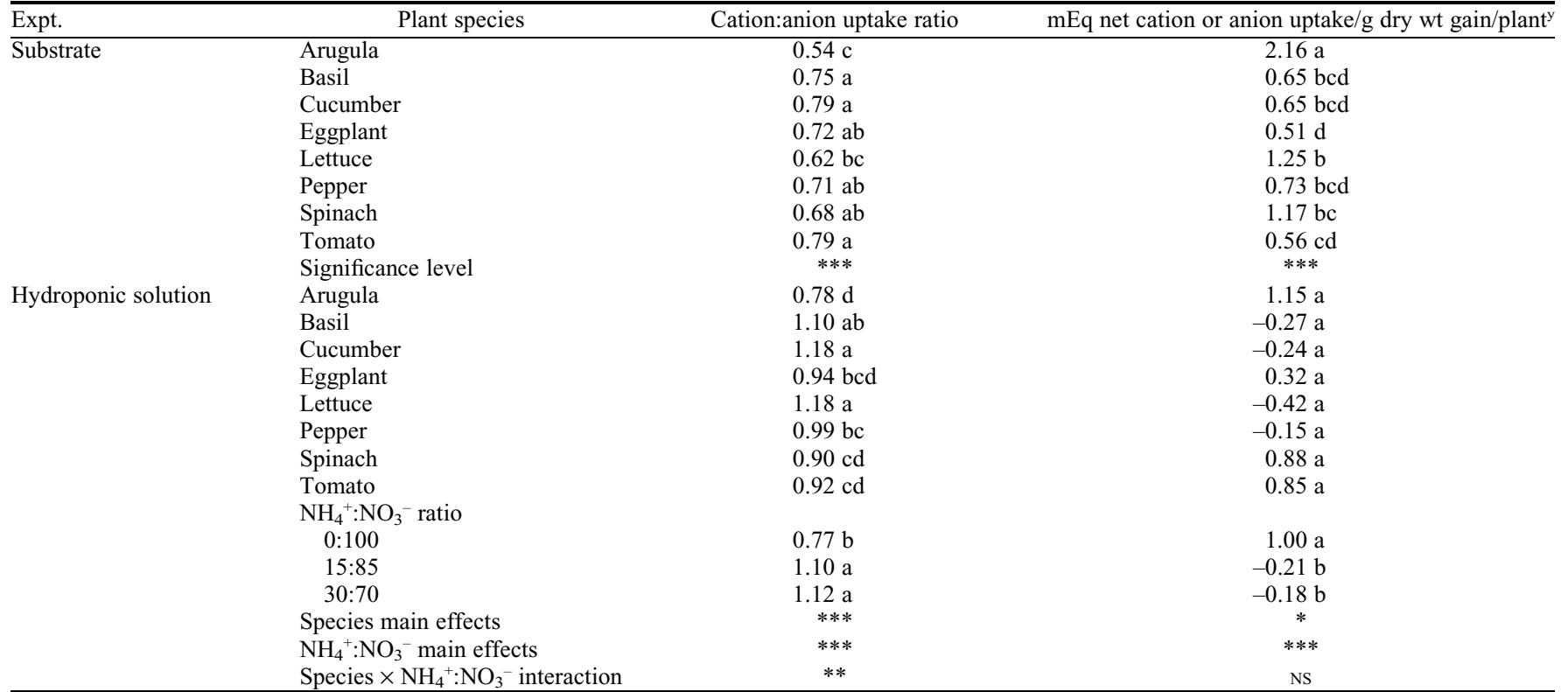

${ }^{\mathrm{z}}$ Substrate experiment data represent least-square means of six replicates per species supplied with a $\mathrm{NH}_{4}{ }^{+}: \mathrm{NO}_{3}{ }^{-}$ratio of $0: 100$. Hydroponic experiment data represent least-square means of 12 replicates per species and 32 replicates per $\mathrm{NH}_{4}^{+}: \mathrm{NO}_{3}{ }^{-}$ratio. Mean separation for species and solution main effects used Tukey's honestly significant difference at $\alpha=0.05$, and means sharing the same lowercase letter were not significantly different.

${ }^{\mathrm{y}}$ Calculated as $\mathrm{mEq}$ of total anions minus $\mathrm{mEq}$ of total cations taken up per gram of dry weight gain per plant.

Ns, ${ }^{*}, * *, * * *$ Not significant or significant at $P<0.05,0.01$, or 0.0001 , respectively

\section{A}

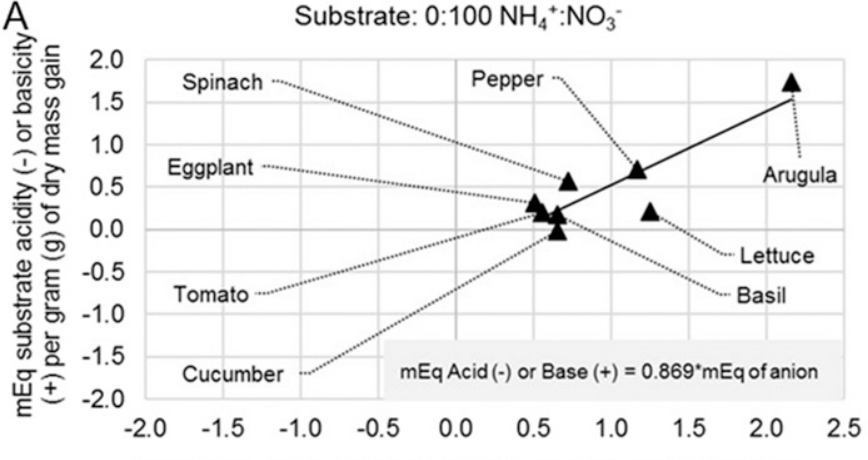

$\mathrm{mEq}$ anion minus cation uptake per gram $(\mathrm{g})$ of dry mass gain

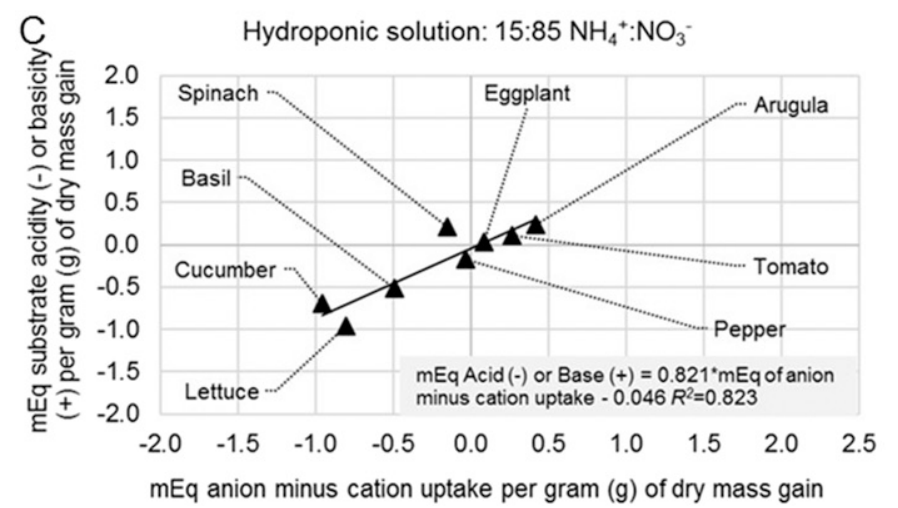

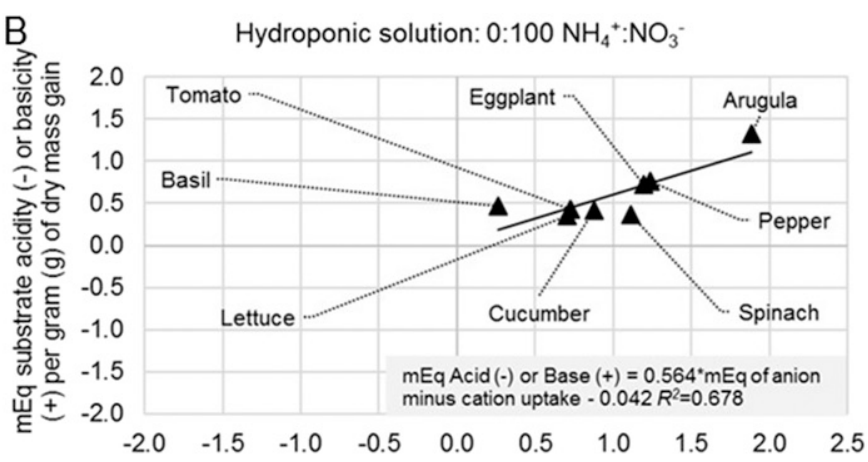

$\mathrm{mEq}$ anion minus cation uptake per gram $(\mathrm{g})$ of dry mass gain

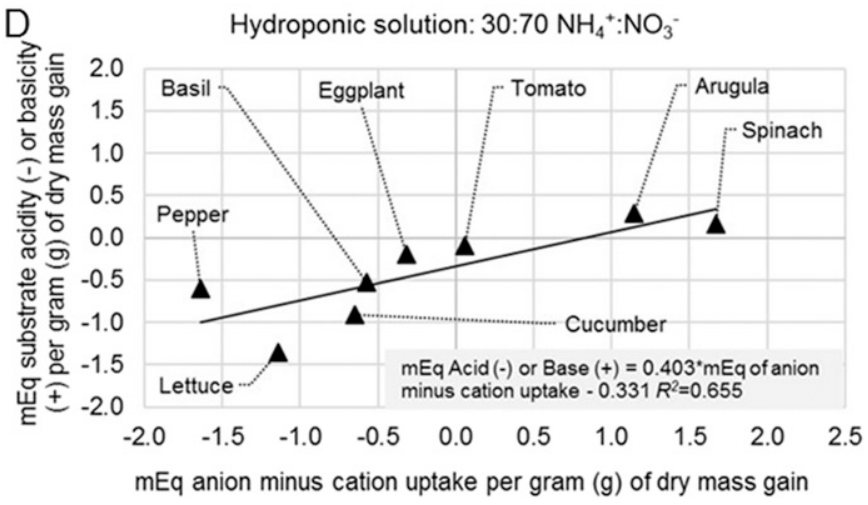

Fig. 2. Species milliequivalents $(\mathrm{mEq})$ of net cation or anion uptake per gram dry weight gain per plant (x-axis) vs. mEq of acid $(-$ value) or base $(+$ value) produced per gram dry weight gain per plant (y-axis). (A) Data from the substrate experiment with a $\mathrm{NH}_{4}{ }^{+}: \mathrm{NO}_{3}{ }^{-}$ratio of $0: 100$, where symbols represent species least-square means from six replicates. (B-D) Data from the hydroponic solution experiment represent species least-square means from four replicates for each $\mathrm{NH}_{4}{ }^{+}: \mathrm{NO}_{3}{ }^{-}$ratio.

As mentioned previously, spinach also had the least average dry weight gain and total nutrient uptake compared with the other species. Species and $\mathrm{NH}_{4}{ }^{+}: \mathrm{NO}_{3}{ }^{-}$ratio $(P<$
0.05), but not their interaction, affected $\mathrm{mEq} \cdot \mathrm{g}^{-1}$ net anion or cation uptake. Overall, arugula had the greatest $\mathrm{mEq} \cdot \mathrm{g}^{-1}$ of net anion uptake (1.15) whereas lettuce had the greatest
$\mathrm{mEq} \cdot \mathrm{g}^{-1}$ of net cation uptake (0.42). Positive correlations $(r>0.8$; data not shown) found between $\mathrm{mEq} \cdot \mathrm{g}^{-1}$ of net cations or anions taken up and $\mathrm{mEq} \cdot \mathrm{g}^{-1}$ of net solution acidity 
and basicity produced for each of the three $\mathrm{NH}_{4}{ }^{+}: \mathrm{NO}_{3}{ }^{-}$ratios indicated that species effects on root zone $\mathrm{pH}$ in hydroponic nutrient solution were largely the result of cation/ anion balance (Fig. 2B-D).

In horticultural practice, commercial growers often produce multiple species in the same production space and it may not be practical to supply each species with a separate $\mathrm{NH}_{4}{ }^{+}: \mathrm{NO}_{3}{ }^{-}$ratio for neutral $\mathrm{pH}$. However, supplying species that differ significantly in their $\mathrm{pH}$ effect, such as cucumber and arugula, with the same fertilizer formulation is likely to result in $\mathrm{pH}$ drift and nutritional problems. In these scenarios, one option may be to group species by their general acidic or basic tendencies and then adjust the $\mathrm{NH}_{4}{ }^{+}: \mathrm{NO}_{3}{ }^{-}$ratio for each group for an about-stable $\mathrm{pH}$ across species.

One limitation of the scope of our study was that experiments were conducted with young plants in their vegetative growth stage. Several authors have reported that stage of plant development influences uptake of individual cation and anion nutrients (Bugbee, 2004; Marschner, 2012; Sonneveld and Voogt, 2009), particularly for fruiting species such as tomato and cucumber. Cation/anion uptake and root zone acidity-basicity may change during the shift from vegetative to reproductive growth stage, which may affect $\mathrm{NH}_{4}{ }^{+}: \mathrm{NO}_{3}{ }^{-}$ratios and neutral percent $\mathrm{NH}_{4}{ }^{+}-\mathrm{N}$ values estimated for tomato, cucumber, eggplant, and pepper in this study.

The potential to adjust the $\mathrm{NH}_{4}{ }^{+}: \mathrm{NO}_{3}{ }^{-}$ratio as a strategy to manage $\mathrm{pH}$ is limited because increasing $\mathrm{NH}_{4}{ }^{+}-\mathrm{N}$ often inhibits the uptake of cations such as $\mathrm{K}^{+}, \mathrm{Ca}^{2+}$, and $\mathrm{Mg}^{2+}$ (Bugbee, 2004; Lea-Cox et al., 1999; van Beusichem et al., 1988). Increasing $\mathrm{NH}_{4}^{+}-\mathrm{N}$ increases susceptibility to certain physiologic disorders related to poor $\mathrm{Ca}^{2+}$ uptake and translocation within the plant, such as "tip burn" in lettuce and "blossom end rot" in tomato (Marschner, 2012; Sonneveld and Voogt, 2009). The influence of $\mathrm{N}$ form on $\mathrm{Ca}^{2+}$ uptake was therefore evaluated in our study for species grown in hydroponic solution. Species differed in $\mathrm{Ca}^{2+}$ uptake $(P<0.0001)$, and increasing the solution $\mathrm{NH}_{4}{ }^{+}: \mathrm{NO}_{3}{ }^{-}$ratio decreased $\mathrm{Ca}^{2+}$ uptake across all species $(P<0.0001)$, but there was no interaction $(P=0.2692)$. Figure $3 \mathrm{~A}$ shows $\mathrm{Ca}^{2+}$ uptake (in $\mathrm{mEq}$ of $\mathrm{Ca}^{2+}$ uptake per gram dry weight gain) was greatest with the $0: 100$ solution (1.13), intermediate with the 15:85 solution $(0.90)$, and least with the $30: 70$ solution $(0.78)$. Uptake of $\mathrm{Ca}^{2+}$ was greatest for cucumber (1.54) and least for spinach (0.38) (Fig. 3B). In addition to limiting $\mathrm{Ca}$ uptake, the risk of ammonium toxicity increases as $\mathrm{NH}_{4}^{+}-\mathrm{N}$ increases greater than $20 \%$ of total $\mathrm{N}$ in hydroponic solutions (Sonneveld and Voogt, 2009). Based on the required neutral percent $\mathrm{NH}_{4}{ }^{+} \mathrm{N}$ values in Table 1 , adjusting the $\mathrm{NH}_{4}{ }^{+}: \mathrm{NO}_{3}{ }^{-}$ ratio alone may not be an effective strategy to control $\mathrm{pH}$ for species such as arugula, eggplant, and tomato in hydroponics or arugula, pepper, and spinach grown in substrate, especially because nutrient solutions were formulated using zero-alkalinity water and substrate was incorporated with hydrated limestone with no residual $\mathrm{pH}$ buffering activity. With certain crops and cultural conditions, other $\mathrm{pH}$ management strategies would therefore be needed. For example, mineral acid injection is required in many horticultural operations to neutralize high concentrations of bicarbonates in irrigation water (Bugbee, 2004; Sonneveld and Voogt, 2009). In substrate culture and when using nitrate-based fertilizer, decreasing the limestone incorporation rate is another strategy to avoid high $\mathrm{pH}$ problems with certain species (Argo and Fisher, 2002).

\section{Conclusions}

This study clearly showed that both plant species and applied $\mathrm{NH}_{4}{ }^{+}: \mathrm{NO}_{3}{ }^{-}$ratio influenced root zone $\mathrm{pH}$ in substrate and hydroponics, which has implications for nutrient management in commercial horticulture. Increasing the $\mathrm{NH}_{4}{ }^{+}: \mathrm{NO}_{3}{ }^{-}$ratio resulted in increased acidity, lower $\mathrm{pH}$, and increased cation uptake. Species differences in $\mathrm{pH}$ effects resulted from differences in cation/anion nutrient uptake, even when supplied with the same $\mathrm{NH}_{4}{ }^{+}: \mathrm{NO}_{3}{ }^{-}$ratio. Adjusting the applied $\mathrm{NH}_{4}{ }^{+}: \mathrm{NO}_{3}{ }^{-}$ratio is one potential strategy to balance species' acidity-basicity for a neutral root zone $\mathrm{pH}$. The percent $\mathrm{NH}_{4}{ }^{+} \mathrm{N}$ of total applied $\mathrm{N}$ expected to result in a neutral root zone $\mathrm{pH}$ was less than $10 \%$ for cucumber and more than $20 \%$ for arugula in both substrate and hydroponics, and overall these species were the most acidic and basic, respectively. The remaining species had neutral percent $\mathrm{NH}_{4}{ }^{+}-\mathrm{N}$ values between $10 \%$ and $20 \%$ in substrate or hydroponics, and tended to be intermediate in their acidity-basicity. In substrate, cucumber produced acidity-basicity not statistically different from zero when supplied with the 0:100 solution, and was estimated to require a nearly $100 \% \mathrm{NO}_{3}{ }^{-} \mathrm{N}$ fertilizer to prevent a decrease in root zone $\mathrm{pH}$. On the other hand, arugula was especially basic and had an estimated neutral percent $\mathrm{NH}_{4}{ }^{+}-\mathrm{N}$ of $46 \%$ in substrate.

Plant species is only one parameter that influences root zone $\mathrm{pH}$ and the $\mathrm{NH}_{4}{ }^{+}: \mathrm{NO}_{3}{ }^{-}$ ratio. Other factors include irrigation water alkalinity, substrate components, nutrient concentrations, limestone type, and incorporation rate. The high level of $\mathrm{pH}$ change in our trials was partly the result of formulating substrates and solutions using hydrated

\section{A}

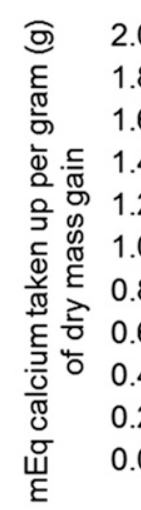

\section{B}

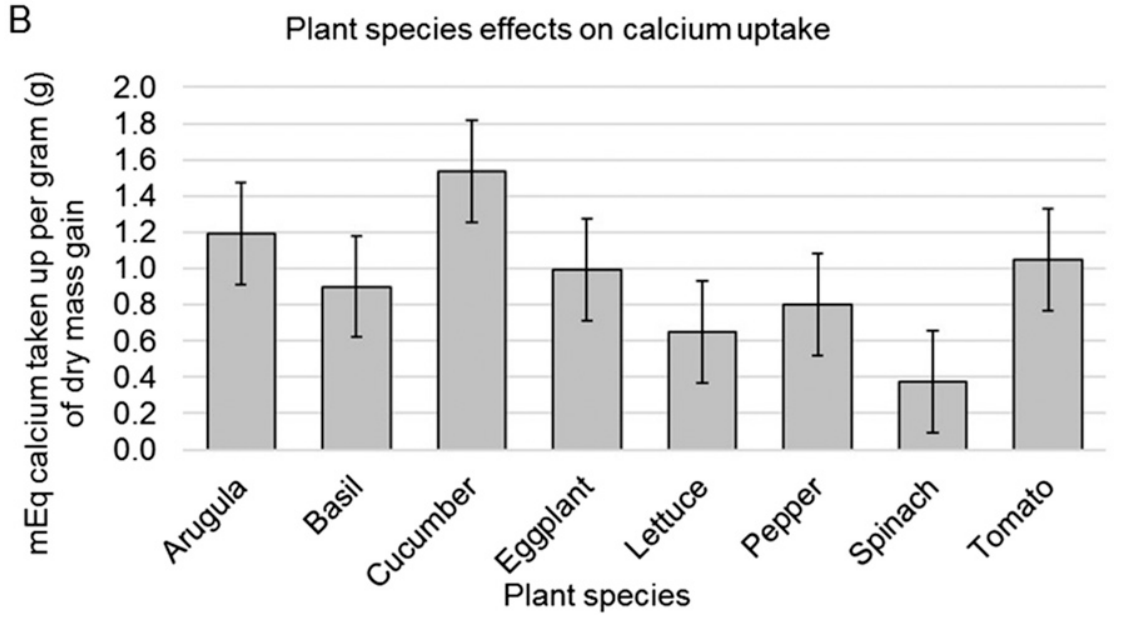

Fig. 3. (A) Solution $\mathrm{NH}_{4}{ }^{+}: \mathrm{NO}_{3}{ }^{-}$ratio and (B) species effects on Ca uptake per gram dry weight gain per plant in hydroponic solution with $\mathrm{NH}_{4}^{+}: \mathrm{NO}_{3}{ }^{-}$ratios of $0: 100,15: 85$, and 30:70. Data represent leastsquare means of 32 replicates for each solution $\mathrm{NH}_{4}{ }^{+}: \mathrm{NO}_{3}{ }^{-}$ratio $(\mathbf{A})$ and 12 replicates for each species. Error bars are $\pm 95 \%$ confidence intervals using Tukey's honestly significant difference at $\alpha=0.05$. 
limestone and zero-alkalinity water, respectively, which resulted in low buffering against change in $\mathrm{pH}$. Although we showed that adjusting the $\mathrm{NH}_{4}{ }^{+}: \mathrm{NO}_{3}{ }^{-}$ratio can control $\mathrm{pH}$, there are limits to this strategy because high $\mathrm{NH}_{4}{ }^{+}-\mathrm{N}$ can decrease the uptake of $\mathrm{Ca}^{2+}$ and other cations and promote ammonium toxicity, affecting plant quality negatively. Based on our results, adjusting the $\mathrm{NH}_{4}{ }^{+}: \mathrm{NO}_{3}{ }^{-}$ratio alone may not be an effective strategy to control $\mathrm{pH}$ for arugula, eggplant, and tomato in hydroponics or arugula, pepper, and spinach grown in substrate. Preventing $\mathrm{pH}$ drift in substrate and hydroponics requires regular $\mathrm{pH}$ monitoring in combination with adjusting $\mathrm{NH}_{4}{ }^{+}: \mathrm{NO}_{3}{ }^{-}$ratios, acid-base injection, and other $\mathrm{pH}$ management strategies.

\section{Literature Cited}

Argo, W.R. and P.R. Fisher. 2002. Understanding $\mathrm{pH}$ management for container-grown crops. Meister Publishing, Willoughby, $\mathrm{OH}$.

Bailey, D.A. 1996. Alkalinity, pH and acidification, p. 69-91. In: D.W. Reed (ed.). Water, media, and nutrition for greenhouse crops. Ball Publishing, Batavia, IL.

Bar-Yosef, B. 2008. Fertigation management and crops response to solution recycling in semiclosed greenhouses, p. 343-419. In: M. Raviv and J.H. Lieth (eds.). Soilless culture: Theory and practice. Elsevier, London, UK.

Bugbee, B. 2004. Nutrient management in recirculating hydroponic culture. Acta Hort. 648:99112.

Conesa, E., D. Niñirola, M.J. Vicente, J. Ochoa, S. Bañòn, and J.A. Fernández. 2009. The influence of nitrate/ammonium ratio on yield quality and nitrate, oxalate, and vitamin $\mathrm{C}$ content of baby leaf spinach and bladder campion plants grown in a floating system. Acta Hort. 843:269-274.

Dickson, R.W., P.R. Fisher, W.R. Argo, D.J Jacques, J.B. Sartain, L.E. Trenholm, and T.H. Yeager. 2016. Solution ammonium:nitrate ratio and cation/anion uptake affect acidity or basicity with floriculture species in hydroponics. Scientia Hort. 200:36-44.

Engels, C. and H. Marschner. 1995. Plant uptake and utilization of nitrogen, p. 41-82. In: P.E. Bacon (ed.). Nitrogen fertilization in the environment. Marcel Dekker, New York, NY.

Fisher, P.R., W.R. Argo, and J.A. Biernbaum. 2014. Validation of a fertilizer potential acidity model to predict the effects of water soluble fertilizer on substrate-pH. HortScience 49:1061-1066.

Hamrick, D. (ed.). 2003. Ball redbook, vol. 2. Crop production. 17th ed. Ball Publishing, Batavia, IL.

Haynes, R.J. 1990. Active ion uptake and maintenance of cation-anion balance: A critical examination of their role in regulating rhizosphere pH. Plant Soil 126:247-264.

Ikeda, H. and T. Osawa. 1983. Effects of ratios of $\mathrm{NO}_{3}$ to $\mathrm{NH}_{4}$ and concentrations of $\mathrm{N}$ source in the nutrient solution on growth and leaf $\mathrm{N}$ constituents of vegetable crops and solution pH. J. Jpn. Soc. Hort. Sci. 52:159-166.

Imas, P., B. Bar-Yosef, U. Kafkafi, and R. GanmoreNeumann. 1997. Release of carboxylic anions and protons by tomato roots in response to ammonium/nitrate ratio and $\mathrm{pH}$ in nutrient solution. Plant Soil 191:27-34.

Johnson, C.N., P.R. Fisher, J. Huang, R.P. Vetanovetz, and W.R. Argo. 2010. Quantifying the acidity of an ammonium-based fertilizer in containerized plant production. HortScience 45:1099-1105.

Johnson, C.N., P.R. Fisher, J. Huang, T.H. Yeager, T.A. Obreza, R.P. Vetanovetz, W.R. Argo, and A.J. Bishko. 2013. Effect of fertilizer potential acidity and nitrogen form on the $\mathrm{pH}$ response in peat-based substrate with three floriculture species. Scientia Hort. 162:135-143.

Kirkby, E.A. and A.H. Knight. 1977. Influence of the level of nitrate nutrition on ion uptake and assimilation, organic acid accumulation, and cation-anion balance in whole tomato plants. Plant Physiol. 60:349-353.

Lang, H.J. and G.C. Elliot. 1990. Influence of ammonium:nitrate ratio and nitrogen concentration on nitrification activity in soilless potting media. J. Amer. Soc. Hort. Sci. 116: 642-645.
Lea-Cox, J.D., W.L. Berry, G.W. Stutte, and R.M. Wheeler. 1999. Nutrient dynamics and $\mathrm{pH} /$ charge-balance relationships in hydroponic solutions. Acta Hort. 481:241-250.

Lea-Cox, J.D., G.W. Stutte, W.L. Berry, and R.M Wheeler. 1996. Charge-balance: A theoretical basis for modulating $\mathrm{pH}$ fluctuations in plant nutrient delivery systems. Life Support Biosph. Sci. 3:53-59.

Lindsay, W.L. 1979. Chemical equilibria in soils. Blackburn Press, Caldwell, NJ.

Marschner, P. 2012. Mineral nutrition of higher plants. 3rd ed. Academic Press, San Diego, CA.

Peterson, J.C. 1981. Modify your $\mathrm{pH}$ perspective. Flor. Rev.169:34-35, 92-93.

Puustjarvi, V. and R.A. Robertson. 1975. Physical and chemical properties, p. 23-38. In: D.W. Robinson and J.G.D. Lamb (eds.). Peat in horticulture. Academic Press, London, UK.

Rengel, Z. 2003. Handbook of soil acidity, vol. 94. CRC Press, Boca Raton, FL.

Resh, H.M. 2001. Hydroponic food production, a definitive guidebook for the advanced home gardener and the commercial hydroponic grower. 6th ed. Woodbridge Press Publishing, Santa Barbara, CA.

Savvas, D., H.C. Passam, and C. Olympios. 2006. Effects of ammonium nitrogen on lettuce grown on pumice in a closed hydroponic system. HortScience 41:1667-1673.

Scharwz, D., S. Ruppel, and R. Kuchenbuch. 1999. Nitrogen cycle and microorganisms in a hydroponic system as influenced by the amount of nitrogen applied. Acta Hort. 481:371-377.

Scoggins, H.L., D.A. Bailey, and P.V. Nelson. 2002. Efficacy of the press extraction method for bedding plant plug nutrient monitoring. HortScience 37:108-112.

Sonneveld, C. and W. Voogt. 2009. Plant nutrition of greenhouse crops. Springer, Dordrecht, Netherlands.

van Beusichem, M.L., E.A. Kirkby, and R. Bass. 1988. Influence of nitrate and ammonium nutrition on the uptake, assimilation, and distribution of nutrients in Ricinus communis. Plant Physiol. 86:914-921. 